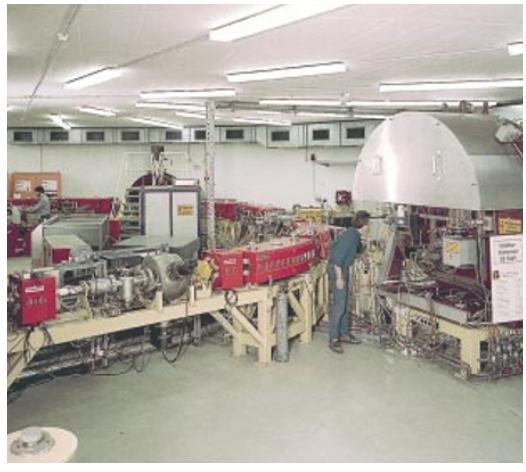

Sesame seed: Berlin's Bessy- 1 could create a new facility in the Middle East.

\section{Funding problems threaten Middle East's synchrotron}

\section{Paris}

Scientists will tour the Middle East this month to drum up support for a planned synchrotron facility, which is threatened by lack of funding.

The Sesame (Synchrotron radiation for Experimental Science and Applications in the Middle East) project would involve moving and upgrading Bessy-1, a decommissioned $0.8 \mathrm{GeV}$ synchrotron radiation source in Berlin. But it must be dismantled and packed by the end of this year. That alone is expected to cost half a million dollars.

Maurizio Iaccarino, United Nations Educational, Scientific and Cultural Organization (Unesco) assistant director-general for natural sciences, and Herwig Schopper, former directorgeneral of the European Laboratory for Particle Physics (CERN) and president of the project's interim council, are to visit several countries that have shown an interest in the project.

Because the facility would be open to scientists of any nationality, organizers see its potential as not only a world-class research centre, but also as a politically important example of scientific cooperation in the region.

"A project costing US\$50 million over ten years needs a strong political commitment," says Siegbert Raither, director of mathematics, physical and chemical sciences at Unesco.

Egypt, Iran, the Palestinian Authority and Armenia have all made official bids to host the centre, and several other countries in the region are supportive. But they are not expected to be able to finance the venture themselves, so organizers need to seek financial aid from the European Union countries and the United States. Heather McCabe

\title{
E-Biomed to be launched as a repository for research
}

\section{Washington}

A centralized database of scientific literature for biology researchers is to be launched in January by the National Institutes of Health (NIH). It will contain the content of many established journals as well as material that has not yet been peer-reviewed.

The repository is the latest manifestation of the E-Biomed electronic publishing proposal, introduced by NIH director Harold Varmus in April (See Nature 399, 8; 1999). Known as PubMed Central, it will be integrated with PubMed, the National Library of Medicine's existing literature database.

It will include reports that have been screened by what the NIH calls "responsible groups" but not formally peer-reviewed. "This material will be clearly distinguishable from the peer-reviewed content of PubMed Central," the proposal says. It is intended as the initial site in a system to be overseen by an international advisory committee.

After an outcry from scientific publishers, the proposal makes clear that the NIH itself will not arrange either for peer review of papers in PubMed Central, or for screening of the non-peer-reviewed section.

Most of the peer-reviewed section of the repository is expected to come from existing scientific journals, whose publishers may make their content available after a short lag time: one scientific society says it may delay the appearance of papers from its journals on PubMed Central by about six months.

Scientists will be able to submit material directly to PubMed Central, if they form themselves into what the proposal calls "any organisation with at least three members who are principal investigators on research grants from major funding agencies".

The new proposal was released on 30 August, when neither Varmus nor David Lipman, head of NIH's National Centre for Biotechnology Information and a key author of the proposal, were available to discuss it. Several of the most strident critics of past E-Biomed proposals were on vacation.

However, Dale Benos, chair of physiology and biophysics at the University of Alabama and head of the publications committee of the American Physiology Society, predicts that the proposal will be welcomed by societies that were initially wary.

"Varmus should be congratulated — he has listened to criticism and reformulated it in a sensible way," says Benos. "There is not going to be an E-Biomed board of editors, it will let individual journals maintain their autonomy, and things will work much as they do now."

Colin Macilwain

\section{Pollard resigns as president of Salk}

\section{San Diego}

The Salk Institute has announced that Thomas Pollard will step down as president at the start of next year, ending months of speculation about leadership at the biomedical research centre at La Jolla, California.

Pollard, who had two years remaining on his five-year administrative contract, will continue as a professor at the Salk, running the institute's structural biology laboratory.

In February, the Salk's board stripped Pollard of his title as chief executive after internal debate over his leadership (see Nature 400, 805; 1999). The board then undertook a governance study — completed in July - and is considering how to apply its recommendations on faculty, board and administrative issues.

"I'm proud of what we've accomplished," said Pollard in a statement. "However, I have decided to step down as president so I can devote more time to my scientific research. This change also will allow me to spend more time on public service, particularly in advocacy for funding for biomedical research."
Frederick Rentschler, chairman of the Salk's board and chief executive since February, issued a statement, thanking Pollard for his "vigorous efforts" as president. Rentschler, a retired corporate executive, became chief executive after some senior faculty members became displeased with Pollard.

Other senior staff, including cell biologist Ian Trowbridge, are concerned that Pollard's ousting will make it difficult to attract another top-flight scientific leader. Asked about plans to replace Pollard, Trowbridge said: "There has been no internal discussion with the faculty on leadership." Stephen Heinemann, chairman of the institute's faculty, declined to comment.

The Salk Institute board has created a sixperson search committee to find a replacement, chaired by investment banker Jerome Kohlberg. It remains unclear how the Salk Institute's executive and scientific leadership will be organized in the future. Institute officials have not released the consultant's report, but some staff may now now push to be told its recommendations. Rex Dalton 